\title{
Correction to: An object-based approach for semi-automated landslide change detection and attribution of changes to landslide classes in northern Taiwan
}

\author{
Daniel Hölbling ${ }^{1} \cdot$ Barbara Friedl $^{1} \cdot$ Clemens Eisank $^{2}$
}

Published online: 20 February 2019

(C) The Author(s) 2019

\section{Correction to: Earth Sci Inform (2015) 8:327-335 https://doi.org/10.1007/s12145-015-0217-3}

The article "An object-based approach for semi-automated landslide change detection and attribution of changes to landslide classes in northern Taiwan", written by Daniel Hölbling, Barbara Friedl, and Clemens Eisank, was originally published electronically on the publisher's internet portal (currently SpringerLink) on 7 April 2015 without open access.

With the author(s)' decision to opt for Open Choice the copyright of the article changed on February 2019 to $($ C) The Author(s) 2015 and the article is forthwith distributed under the terms of the Creative Commons Attribution 4.0 International License (http://creativecommons.org/licenses/ by/4.0/), which permits use, duplication, adaptation, distribution and reproduction in any medium or format, as long as you give appropriate credit to the original author(s) and the source, provide a link to the Creative Commons license and indicate if changes were made.

The original article has been corrected.

Open Access This article is distributed under the terms of the Creative Commons Attribution 4.0 International License (http:// creativecommons.org/licenses/by/4.0/), which permits unrestricted use, distribution, and reproduction in any medium, provided you give appropriate credit to the original author(s) and the source, provide a link to the Creative Commons license, and indicate if changes were made.

Publisher's note Springer Nature remains neutral with regard to jurisdictional claims in published maps and institutional affiliations.

The online version of the original article can be found at https://doi.org/ $10.1007 / \mathrm{s} 12145-015-0217-3$

Daniel Hölbling

daniel.hoelbling@sbg.ac.at

1 Department of Geoinformatics - Z_GIS, University of Salzburg, Salzburg, Austria

2 GRID-IT Gesellschaft für angewandte Geoinformatik mbH, Innsbruck, Austria 